\title{
NIEDZIELA W ŻYCIU KOŚCIOŁA PARTYKULARNEGO
}

Niedziela po II Soborze Watykańskim z nową mocą w przeżywaniu roku liturgicznego jednoczy przede wszystkim Kościół powszechny i wszystkich chrześcijan. Zarazem jednak staje się szczególnym znakiem, rzeczywistością i dziedzictwem Kościołów partykularnych, zwłaszcza diecezji i parafii ${ }^{1}$.

\section{ZNACZENIE PRZEŻYWANIA NIEDZIELI}

Nie przypadkiem niedzieli $\mathrm{w}$ szczególny sposób odpowiada pojęcie nie tylko jej zachowywania, obchodzenia, ale przede wszystkim przeżywania. „Prze-żywanie” wskazuje na szczególny związek z życiem, życiem Kościoła i chrześcijanina w Kościele, zwłaszcza partykularnym. To zarazem pojęcie czerpania z niedzieli życia oraz dawania świadectwa

* Ks. Andrzej Rutkowski - dr, prezbiter diecezji pelplińskiej, adiunkt w Katedrze Teologii Liturgii Katolickiego Uniwersytetu Lubelskiego Jana Pawła II.

${ }^{1}$ Jan Paweł II, List apostolski „Dies Domini” o świętowaniu niedzieli (31 V 1998), nr 35, „L'Osservatore Romano. Wydanie polskie” 19 (1998), nr 8-9, s. 14; Benedykt XVI, Posynodalna adhortacja apostolska "Verbum Domini” o stowie Bożym w życiu i misji Kościota (30 IX 2010), nr 92, Kraków 2010, s. 100-101. 
wiary na fundamencie znaczenia i wagi tego dnia oraz formacji do jego przeżywania $^{2}$. W ten sposób refleksję Kościołów partykularnych może skupiać, a jednocześnie rozwijać prawda, że niedziela to rdzeń i podstawa roku liturgicznego (por. KL 102; KKK 2177). Tym samym także tylko i wyłącznie na kanwie tej prawdy zrozumienie w tych Kościołach mogą zyskiwać tak szczegółowe zasady, jak przenoszenie uroczystości zbieżnych z niedzielą dawniej na sobotę, a obecnie na poniedziałek czy - zwłaszcza w Kościele Krakowskim z perspektywy roku 1979 i Częstochowskim w dobie roku 1986 - doświadczenie łączenia maryjnego charakteru soboty z przygotowaniem do niedzieli ${ }^{3}$. Życie Kościołów partykularnych może więc składać się na pogłębianie wciąż na nowo w Kościele powszechnym przekonania, że w odpowiednim sposobie przeżywania niedzieli spełnia się autentyzm wiary, dar czasu i znaczenie tradycji ${ }^{4}$.

Ponadto do świadomości Kościołów partykularnych wciąż zdaje się powracać troska o ochronę przed laicyzacją sakralnego charakteru dnia niedzielnego. Nie można więc kojarzyć go jedynie z wypoczynkiem i zakończeniem tygodnia oraz z angielską nazwą ",weekend”. Kościołom partykularnym towarzyszy także przekonanie, że pewne niebezpieczeństwo stanowi dla niedzieli wprowadzenie wolnych sobót oraz zatrata poczucia sakralnego charakteru niedzieli. W tej dziedzinie pojawia się nowe zagrożenie. Są to giełdy samochodowe, bazary handlowe, praca w polu i na działkach oraz mecze i widowiska w niedzielne przedpołudnia. Ich wyjątkowe oddziaływanie łączy się z obojętnością oraz małą wiarą

${ }^{2}$ L. Bertsch, Stirbt der Sonntag am Wochenende?, „Liturgisches Jahrbuch" 31 (1981), s. 161-162; M. Sodi, Celebrare la fede nel tempo, „Rivista Liturgica” 81 (1994), s. 771; J. J. Kopeć, Niedziela - dzień dni, „Roczniki Teologiczne” 47 (2000), z. 8, s. 152-153; S. Jankowski, "Abyś dzień święty święcit”, w: Pamiętaj, abyś dzień święty święcit, red. K. Konecki, Toruń 2011, s. 28-29 (Seria: „Scripta Theologica Thoruniensia”, t. 17).

${ }^{3}$ Synod diecezji wtoctawskiej odbyty we Wtoctawku w dniach 6-9 XI 1967 r. pod przewodnictwem księdza biskupa Antoniego Pawtowskiego, biskupa włoctawskiego (Statuty i załączniki) (9 XI 1967), „Kronika Diecezji Włocławskiej” 51 (1968), s. 108; Trzeci synod archidiecezji warszawskiej (12 IX 1974), „Wiadomości Archidiecezjalne Warszawskie” 65 (1975), s. 132; Duszpasterski synod archidiecezji krakowskiej 1972-1979. Przebieg prac synodalnych. Dokumenty synodu. Dokumentacja synodu (8 V 1979), t. 1, Kraków 1985, s. 334, 491; Chrystus świattem, Maryja wzorem. Drugi synod diecezji częstochowskiej (23 XI 1986), Częstochowa 1987, s. 119, 126, 131, 257; Synod archidiecezji wroctawskiej 1985-1991 (6 XII 1993), Wrocław 1995, s. 301, 303.

${ }^{4}$ Kongregacja Kultu Bożego, Ogólne normy roku liturgicznego i kalendarza (14 II 1969), nr 5, w: Mszat rzymski dla diecezji polskich (28 IV 1984), Poznań 1986, s. [66]; Jan Paweł II, List apostolski „Dies Domini”, nr 7, 76, 79, s. 5-6, 26-27. 
w zmartwychwstanie. To większe niebezpieczeństwo niż dotychczasowe czyny społeczne oraz tendencyjna organizacja wypoczynku dzieci i młodzieży podczas ferii czy wakacji ${ }^{5}$. W ten sposób doświadczenie Kościołów partykularnych otrzymało zwieńczenie w trosce Kościoła powszechnego o kształtowanie dojrzałości i aktywności duchowej oraz poszerzanie horyzontów wiary i myślenia chrześcijan przez przeżywanie niedzielí ${ }^{6}$.

Co do katechezy na temat teologii dnia Pańskiego i formacji do przeżywania niedzieli, przed Kościołami partykularnymi wciąż pojawia się zadanie obejmowania nią nie tylko dzieci i młodzieży, lecz również dorosłych. W Kościele Wrocławskim na miarę roku 1993 po II Soborze Watykańskim, być może pod wpływem sugestii wszystkich diecezji polskich, przedstawiono ideę edycji specjalnego zestawu katechez o niedzieli dla dzieci, młodzieży i dorosłych

\section{NIEDZIELA DNIEM ZMARTWYCHWSTANIA}

Przeżywanie i upamiętnianie w niedzielę przede wszystkim zmartwychwstania Jezusa Chrystusa wciąż wydaje się we wspólnotach Kościołów partykularnych ważnym zadaniem wobec niedostatku świadomości w tej dziedzinie wśród wiernych oraz nazywania niedzieli nie pierwszym, ale ostatnim dniem tygodnia ${ }^{8}$. Tym samym każdy Kościół partykularny po-

${ }^{5}$ Statuty archidiecezjalnego synodu poznańskiego, odprawionego pod przewodnictwem księdza arcybiskupa Antoniego Baraniaka w dniach 4 VI, 12 IX $i 12$ X millenijnego Roku Pańskiego 1968 (14 X 1970), Poznań 1972, s. 18; Trzeci synod archidiecezji warszawskiej, s. 132; Pierwszy synod prowincji krakowskiej (1983). Communio et communication, Kraków 1992, s. 70; Czwarty synod diecezji tarnowskiej 1982-1986. Ad imaginem Ecclesiae universalis (Lumen gentium 23) (13 III 1986), Tarnów 1990, s. 87; Chrystus świattem, s. 94, 120; Drugi synod diecezji lubelskiej 1977-1985 (8 XII 1987), Lublin 1988, s. 158; Drugi polski synod plenarny. Teksty robocze (20 IV 1991), Poznań 1991, s. 83; Uchwaty synodu archidiecezji w Lubaczowie (10 XI 1990), Lubaczów 1991, s. 49; Synod archidiecezji wrocławskiej, s. 337.

6 Jan Paweł II, List apostolski "Dies Domini", nr 4, s. 5.

${ }^{7}$ Drugi polski synod plenarny, s. 90; Uchwaty czterdziestego drugiego synodu płockiego (7 VI 1991), „Miesięcznik Pasterski Płocki” 76 (1991), nr 10 bis, s. 78; Synod archidiecezji wroctawskiej,s. 304.

${ }^{8}$ Ph. Harnoncourt, Der Tag des Herrn, „Heiliger Dienst” 37 (1983), s. 66-67; B. Nadolski, Niedziela sakramentem Paschy, „Ruch Biblijny i Liturgiczny” 41 (1988), s. 412; Z. Wit, Niedziela dniem Chrystusa, „Roczniki Teologiczne” 47 (2000), z. 8, s. 35-36; H. J. Sobeczko, Świętowanie niedzieli w parafii, w: Niedziela w społeczeństwie pluralistycznym, red. E. Mateja, R. Pierskała, Opole 2001, s. 154-155; M. Mejzner, Świętować czy odpoczywać? Refleksje o przeżywaniu niedzieli w pierwotnym Kościele, w: Pamiętaj, abyś dzień, s. 39-40. 
winien uznać ten dzień za najstarszy i główny chrześcijański dzień świąteczny oraz cotygodniowa celebracja paschalnego misterium zmartwychwstania (por. KL 106; KKK 1343)9 . To zadanie uzyskało także dodatkową motywację w związku z głosem Kościoła powszechnego na temat przeżywania w niedzielę daru nadziei, radości, pokoju i dziedzictwa poprzednich pokoleń ${ }^{10}$. Wydaje się, że szczególnie w refleksji Kościoła Tarnowskiego w roku 1986 i Lubaczowskiego w roku 1990 należy uwydatnić stosowanie pojęcia niedzielnego sakramentu zmartwychwstania (por. KL 6) ${ }^{11}$. Przy czym w wielu Kościołach partykularnych upowszechnienia zdaje się wymagać termin „dzień Pański”, a nie tylko „niedziela”"12. Na ogół jednak wiara w zmartwychwstanie Chrystusa stanowi w świadomości Kościołów partykularnych podstawę do radości niedzielnej, a tej radości towarzyszy uwielbienie, dziękczynienie, oczekiwanie powtórnego przyjścia Zbawiciela w chwale, myśl o wieczystej niedzieli oraz nadzieja przyszłego zmartwychwstania przy zachowaniu możliwości godziwej rozrywki w gronie rodzinnym ${ }^{13}$.

\section{NIEDZIELA DNIEM EUCHARYSTII}

Rzeczywistość niedzieli i Kościoła partykularnego w szczególny sposób łączy w sobie misterium Eucharystii dzięki jedno-

9 Synod diecezji wtoctawskiej, s. 108; Statuty archidiecezjalnego synodu poznańskiego, s. 146; Trzeci synod archidiecezji warszawskiej, s. 114, 132-133, 202; Wiara, modlitwa $i \dot{z y c i e} w$ Kościele Katowickim. Uchwaty pierwszego synodu diecezji katowickiej (23 XI 1975), Katowice-Rzym 1976, s. 60-61; Duszpasterski synod archidiecezji krakowskiej, t. 1, s. 334; Pierwszy synod prowincji krakowskiej, s. 37; Czwarty synod diecezji tarnowskiej, s. 132; Chrystus świattem, s. 119-120; Drugi synod diecezji lubelskiej, s. 93; Drugi polski synod plenarny, s. 77; Uchwaty synodu archidiecezji w Lubaczowie, s. 79-80; Synod archidiecezji wroctawskiej, s. 141, 284, 301, 303; Trzeci synod diecezji kieleckiej 1984-1991 (3 VI 1992), Kielce 1992, s. 210.

${ }^{10}$ Kongregacja Kultu Bożego, Instrukcja „Eucharisticum mysterium” (25 V 1967), nr 25, w: To czyńcie na moja pamiątkę. Eucharystia w dokumentach Kościoła, red. J. Miazek, Warszawa 1987, s. 170; por. Kongregacja Kultu Bożego, Ogólne normy, nr 4, s. [66]; Jan Paweł II, List apostolski "Dies Domini”, nr 21, s. 10.

${ }^{11}$ Czwarty synod diecezji tarnowskiej, s. 103, 132; Uchwaty synodu archidiecezji w Lubaczowie, s. 80.

${ }^{12}$ Trzeci synod archidiecezji warszawskiej, s. 51, 114; Czwarty synod diecezji tarnowskiej, s. 103, 132; Chrystus świattem, s. 119; Uchwaty synodu archidiecezji w Lubaczowie, s. 80.

${ }^{13}$ Trzeci synod archidiecezji warszawskiej, s. 132-133, 202; Duszpasterski synod archidiecezji krakowskiej, t. 1, s. 335; Chrystus świattem, s. 120-121; Drugi synod diecezji lubelskiej, s. 94, 158; Drugi polski synod plenarny, s. 76-77, 325; Trzeci synod diecezji kieleckiej, s. $210-211,219$. 
ści misterium Jezusa Chrystusa w Jego męce, śmierci i zmartwychwstaniu ${ }^{14}$.

\subsection{ROLA I ZNACZENIE MSZY ŚW. W NIEDZIELE I UROCZYSTOŚCl OBOWIĄZUJĄCE}

W Kościele partykularnym na różne sposoby spełnia się przekonanie, że Msza św. to centrum oraz istota niedzieli i obowiązującej uroczystości ${ }^{15}$. Tym samym prawda ta nie zatrzymuje się na obowiązku udziału we Mszy św. niedzielnej ze strony ludu Bożego, lecz pogłębia go z myślą o autentycznym przeżyciu wiary i wspólnoty (por. KPK 528 § 2; KK 3; KKK 1166) ${ }^{16}$.

Według licznych ocen Kościołów partykularnych we współczesnej religijności i życiu liturgicznym wiernych zasadniczo nastąpił wzrost znaczenia niedzielnej Eucharystii. Formację w tym kierunku nadal należy jednak podejmować podczas katechizacji oraz $\mathrm{w}$ rodzinach ${ }^{17}$. Ponadto na miarę roku 1975 po Soborze, Kościół Katowicki skupiał się na trosce, aby ci wierni, którzy z uwagi na pracę zawodową w żaden sposób nie mogą uczęszczać na niedzielną Eucharystię, dopełniali tego chrześcijańskiego obowiązku w innym dniu tygodnia ${ }^{18}$. O tym, że transmisja radiowa jest przeznaczona wyłącznie dla chorych i starszych, którzy nie mogą brać

${ }^{14}$ Jan Paweł II, List apostolski „Dies Domini”, nr 33, s. 13; Benedykt XVI, Posynodalna adhortacja, nr 55, s. 66-67.

${ }^{15}$ Cz. Krakowiak, Niedzielna Eucharystia w parafii, w: Eucharystia. Misterium Ofiara - Kult, red. J. J. Kopeć, Lublin 1997, s. 94-95; K. Konecki, Niedzielne zgromadzenie centrum i cel życia chrześcijanina, w: Pamiętaj, abyś dzień, s. 52-53; R. Falsini, La peculiaritá teologico-pastorale della domenica, "Rivista di pastorale liturgica” 29 (1991), nr 2, s. 42-43; Ph. Harnoncourt, Die versammelte Gemeinde fiert Liturgie, „Heiliger Dienst” 52 (1998), s. 47.

${ }^{16}$ Kongregacja Kultu Bożego, Instrukcja "Eucharisticum misterium”, nr 18, s. 167; List Jana Pawta II o tajemnicy i kulcie Eucharystii (24 II 1980), nr 4, w: To czyńcie, s. 245-246; Jan Paweł II, List apostolski „Dies Domini”, nr 32, s. 13.

17 Synod diecezji włoctawskiej, s. 94; Statuty archidiecezjalnego synodu poznańskiego, s. 41; Trzeci synod archidiecezji warszawskiej, s. 51; Duszpasterski synod archidiecezji krakowskiej, t. 1, s. 472; Pierwszy synod prowincji krakowskiej, s. 67; Czwarty synod diecezji tarnowskiej, s. 122, 132, 235; Chrystus świattem, s. 91; Drugi synod diecezji lubelskiej, s. 74, 179; Uchwaty synodu archidiecezji w Lubaczowie, s. 62, 80, 203; Uchwaty czterdziestego drugiego synodu płockiego, s. 63, 77, 88, 110; Synod archidiecezji wroctawskiej, s. 304; Trzeci synod diecezji kieleckiej, s. 219; Poznański synod archidiecezjalny 1992-1993 (31 XII 1993). Dokumenty, Poznań [b.r.w.], s. 182, 185-186, 258, 288.

${ }^{18}$ Wiara, modlitwa $i$ życie, s. 59. 
udziału we Mszy św. w kościele, przypominano w Kościele Częstochowskim w roku 1986 ${ }^{19}$. W ogóle zadaniem Kościołów partykularnych pozostaje troska o pogłębienie motywacji udziału. Obejmuje ona wiarę w zmartwychwstanie, w obecność Chrystusa w zgromadzeniu wiernych jako konsekwencję przyjętego chrztu i bierzmowania, udziału w katechezie oraz przynależności do Kościoła (por. KKK 1167) ${ }^{20}$.

\subsection{PORA CELEBRACJI NIEDZIELNEJ I ŚWIĄTECZNEJ MSZY ŚW.}

Na kanwie podejmowania innowacji i złagodzeń w tej dziedzinie w różnych okresach XX wieku potwierdzono po II Soborze Watykańskim normę, że poza niektórymi tylko dniami Mszę św. można sprawować o jakiejkolwiek porze ${ }^{21}$. Tym samym wspólną troską w Kościołach partykularnych może pozostawać w tej dziedzinie celebracja w porze najdogodniejszej dla wiernych ${ }^{22}$. Nie sprzeciwia się to zarazem naciskowi na stały rozkład niedzielnych celebracji eucharystycznych ${ }^{23}$.

\subsubsection{NIEDZIELNA I ŚWIĄTECZNA MSZA ŚW. W SOBOTĘ WIECZOREM ORAZ W WIGILIĘ UROCZYSTOŚCl}

Nie od razu fakt, że niedziela w Kościele od roku 1960 na powrót rozpoczyna się pierwszymi nieszporami w sobotę, wpłynął na celebrację

19 Chrystus świattem, s. 73.

${ }^{20}$ Trzeci synod archidiecezji warszawskiej, s. 114, 133; Wiara, modlitwa $i \dot{z} y c i e$, s. 60-61; Pierwszy synod prowincji krakowskiej, s. 37, 68, 78; Czwarty synod diecezji tarnowskiej, s. 103; Chrystus świattem, s. 13, 120; Drugi synod diecezji lubelskiej, s. 94; Drugi polski synod plenarny, s. 77, 79-80; Uchwaty czterdziestego drugiego synodu ptockiego, s. 16; Trzeci synod diecezji kieleckiej, s. 211, 219; Synod archidiecezji wroctawskiej, s. 280, 285, 303-304; Poznański synod archidiecezjalny, s. 288.

${ }^{21}$ R. Kamiński, Wspólnototwórcza rola Eucharystii, w: Jezus eucharystyczny, red. M. Rusecki, M. Cisło, Lublin 1997, s. 183-184; B. W. Zubert, Eucharystia w życiu $i$ postudze kaptana, w: Ineffabile Eucharistiae donum, red. T. Dola, Opole 1997, s. 478-479; Cz. Krakowiak, Niedziela dniem Kościoła, „Roczniki Teologiczne” 47 (2000), z. 8, s. 67-68; K. Konecki, dz. cyt., s. 58-59.

22 Synod diecezji wtoctawskiej, s. 98; Statuty archidiecezjalnego synodu poznańskiego, s. 149; Statuty drugiego synodu gdańskiego (20 XII 1973), Gdańsk-Oliwa 1976, s. 62, 167; Czwarty synod diecezji tarnowskiej, s. 120-121; Chrystus świattem, s. 93; Uchwaty synodu archidiecezji w Lubaczowie, s. 59; Uchwaty czterdziestego drugiego synodu płockiego, s. 63, 119.

${ }^{23}$ Duszpasterski synod archidiecezji krakowskiej, t. 1, s. 263; Uchwaty czterdziestego drugiego synodu płockiego, s. 68. 
już w sobotę wieczorem Mszy św. jak w niedzielę ${ }^{24}$. Początkowo wskazywano jedynie na ułatwienie udziału we Mszy św. niektórym wiernym, zwłaszcza z uwagi na warunki pracy, a nie zauważano teologii rozpoczynania niedzieli w sobotę wieczorem przez celebrację Eucharystii jak w niedzielę (por. KPK $202 \S 1)^{25}$. W Polsce ta praktyka nadal spotyka się $\mathrm{w}$ wielu przypadkach $\mathrm{z}$ rezerwą oraz różnorakimi interpretacjami ${ }^{26}$. Wydaje się, że zasadniczo w roku 1987 podjął tę kwestię Kościół Lubelski, ale początkowo nie wykraczano poza ogólne zasady tego typu celebracji. Dotyczą one możliwości wypełnienia przez wiernych obowiązku udziału we Mszy św. niedzielnej lub świątecznej w sobotę wieczorem bądź dzień przedświąteczny (por. KPK 1248 § 1; KKK 2180). W Kościele Koszalińsko-Kołobrzeskim w roku 1989 w praktyce tej ukazywano rozwiązanie problemu trynacji oraz konieczności celebracji czwartej Mszy św. w niedziele i dni świąteczne przez niektórych prezbiterów ${ }^{27}$. Szczegółowe ustalenia podjęto w tej dziedzinie w Kościele Tarnowskim w roku 1986, Lubaczowskim w roku 1990 i Wrocławskim w roku 1993. Podawano tutaj warunek, aby odpowiednia była liczba uczestników oraz by celebrację rozpoczynać nie wcześniej niż o godzinie 16. Ponadto uwrażliwiano na zastosowanie niedzielnej lub odpowiednio świątecznej Liturgii słowa i homilii, jako że jest to pierwsza Msza św. niedzielna lub świąteczna ${ }^{28}$. Nie ma jednak jednolitego stanowiska w sprawie celebracji Mszy św. wraz z zawieraniem sakramentu małżeństwa. Co prawda, już w roku 1974 w Kościele Warszawskim przyjęto praktykę: "Zaleca się dążyć do

${ }^{24}$ H. Dobiosch, Die Vorabendmesse als Sonntagsgottesdienst, "Theologisch-praktische Quartalschrift" 134 (1986), s. 44-45; H. J. Sobeczko, Teologiczny i pastoralny wymiar święcenia niedzieli w sobotni wieczór, „Ruch Biblijny i Liturgiczny” 47 (1994), s. 169-170; Cz. Krakowiak, Niedziela dniem, s. 68-69; K. Konecki, dz. cyt., s. 52-53.

${ }^{25}$ Kongregacja do spraw Biskupów, Dyrektorium o pasterskiej postudze biskupów (22 II 1973), nr 86d, w: Posoborowe prawodawstwo kościelne, t. 6, z. 1, tłum. i red. E. Sztafrowski, Warszawa 1975, s. 126-127; por. Kongregacja Kultu Bożego, Ogólne normy, nr 3, s. [66].

${ }^{26}$ Komunikat biskupów w sprawie obowiazku Mszy św. niedzielnej, który może być spetniony w sobote wieczorem [3 XII 1983], "Częstochowskie Wiadomości Diecezjalne” 58 (1984), s. 54-55 („Orędownik Diecezji Chełmińskiej” 34 (1983), s. 436-437); Komisja Liturgiczna Diecezji Opolskiej, Msza święta w sobotni wieczór początkiem świętowania niedzielnego (17 III 1984), „Ruch Biblijny i Liturgiczny” 38 (1985), s. 248.

${ }^{27}$ Drugi synod diecezji lubelskiej, s. 94; Pierwszy synod diecezji koszalińsko-kołobrzeskiej, s. 79; Drugi polski synod plenarny, s. 93; Synod archidiecezji wroctawskiej, s. 285, 305; Drugi synod diecezji wtoctawskiej, s. 45.

${ }^{28}$ Czwarty synod diecezji tarnowskiej, s. 122; Pierwszy synod diecezji koszalińsko-kołobrzeskiej, s. 104; Uchwaty synodu archidiecezji w Lubaczowie, s. 62; Synod archidiecezji wroctawskiej, s. 305. 
tego, by sakrament małżeństwa błogosławiony w soboty wieczorem łączył się ze Mszą świętą. Używa się wtedy formularza niedzielnego"29. Lecz zarazem w roku 1979 odmiennie potraktowano ten problem w Kościele Krakowskim, uznając, że celebracja mszalna w sobotę wieczorem nie zwalnia z obowiązku udziału w Mszy św. w sam dzień niedzielny ani nowożeńców, ani ich gości ${ }^{30}$.

\subsection{LICZBA CELEBRACJI NIEDZIELNYCH I ŚWIĄTECZNYCH MSZY ŚW.}

Pełnię znaku budowania wspólnoty przez misterium Eucharystii oddawałaby jedna i jedyna Msza św. w niedzielę i uroczystość obowiązująca z udziałem danej wspólnoty Kościoła partykularnego, zwłaszcza parafii, jednak nie zawsze pozwala na to wielkość budynku kościoła czy warunki życia poszczególnych wiernych itp. ${ }^{31} \mathrm{~W}$ Kościele powszechnym odpowiada to dążeniu do oddziaływania misterium Eucharystii na budowanie ducha wspólnoty pośród wiernych, a zarazem do zapewnienia odpowiednich warunków posługi duszpasterzy ${ }^{32}$. Tym samym w Kościele Warszawskim zwłaszcza w roku 1974 i Częstochowskim w roku 1986 odradzano Msze św. w niedziele i święta z udziałem małych zespołów zamkniętych, a wspólnoty zakonne zachęcano do uczestnictwa w niej w kościołach parafialnych (por. KL 42; KKK 2179) ${ }^{33}$. Zarazem w roku 1989 w Kościele Koszalińsko-Kołobrzeskim, na podstawie czasowego pozwolenia prymasowskiego, potwierdzano możliwość czwartej liturgii eucharystycznej pod przewodnictwem tego samego prezbitera, zgodę na tę celebrację pozostawiano jednak w gestii biskupa diecezjalnego i wskazywano na potrzebę indywidualnego rozpatrywania każdego przypad$\mathrm{ku}^{34}$. Osobliwe stanowisko w roku 1986 zajmował Kościół Częstochowski: „W szczególnych okolicznościach, gdy kapłan nie ma już możliwości odprawienia Mszy św. w niedzielę lub święto albo gdy brak kapłana, zaleca się, by wierni uczestniczyli w obrzędzie Komunii św. z dłuższą

${ }^{29}$ Trzeci synod archidiecezji warszawskiej, s. 114.

${ }^{30}$ uszpasterski synod archidiecezji krakowskiej, t. 1, s. 329.

${ }^{31}$ F. Kohlschein, Wenn reduziert werden muß... Zum zeitlichen Ansatz der Sonnund Festtagsmesse, „Gottesdienst” 27 (1993), s. 153-155; Cz. Krakowiak, Ile Mszy św. w parafii?, "Collectanea Theologica” 64 (1994), z. 1, s. 108-109; K. Konecki, dz. cyt., s. 60-61.

${ }^{32}$ Kongregacja Kultu Bożego, Instrukcja „Eucharisticum mysterium", nr 26, s. 171.

${ }^{33}$ Trzeci synod archidiecezji warszawskiej, s. 114; Chrystus świattem, s. 92.

${ }^{34}$ Pierwszy synod diecezji koszalińsko-kotobrzeskiej, s. 79. 
liturgią słowa Bożego" (por. KPK 1248 § 2) ${ }^{35}$. To ciekawe, że aż dotąd na ogół nikt w Polsce nie skojarzy z niedzielą tej możliwości i praktyki w Kościele powszechnym wraz z odpowiednim pełnieniem swojej posługi przez lektora itp. ${ }^{36}$

Dążąc do odpowiedniej liczby celebracji w życiu Kościołów partykularnych, zalecano, aby odstępy między rozpoczęciem kolejnych Mszy św. w niedziele i święta, zwłaszcza od roku 1981, były nie mniejsze niż półtorej godziny ${ }^{37}$. Zasadniczo ogółowi Kościołów partykularnych diecezji polskich w roku 1991 odradzano celebrację niedzielnej Eucharystii co godzinę. W uzasadnieniu przywoływano spostrzeżenie, że niejednokrotnie celebracja co godzinę prowadzi do stosowania najkrótszych modlitw, zbyt częstego wyboru II Modlitwy eucharystycznej oraz do zupełnego braku chwil milczenia ${ }^{38}$.

\subsection{MSZE ŚW. W UROCZYSTOŚCl OBOWIĄZUJĄCE NIEUZNAWANE PRZEZ PAŃSTWO}

Decyzją władzy państwowej niektóre obowiązujące święta kościelne w Polsce nie były uznawane za dni wolne od pracy aż do wydania odpowiednich decyzji samego Kościoła w roku 2003 przez przeniesienie na niedzielę lub zniesienie obowiązku świętowania w ciągu tygodnia, ale przy zachowaniu zachęt do świętowania i udziału we Mszy św. już nie z obowiązku, ale z prawdziwej potrzeby serca ${ }^{39}$. Od roku 1951 to nieuznawanie przez władzę państwową dotyczyło uroczystości Wniebowstąpienia Pańskiego, Niepokalanego Poczęcia Najświętszej Maryi Panny (8 grudnia) oraz świętych apostołów Piotra i Pawła (29 czerwca). Ponadto w latach

${ }_{35}$ Chrystus świattem, s. 93.

${ }^{36}$ Kongregacja Kultu Bożego, Ogólne wprowadzenie do Mszału rzymskiego. Z trzeciego wydania Mszatu rzymskiego. Rzym 2002 (6 XI 2003), nr 197, Poznań 2004, s. 63; por. Komunia święta i kult tajemnicy eucharystycznej poza Msza święta dostosowane do zwyczajów diecezji polskich (7 VI 1980), nr 26, 29, Katowice 2008, s. 22, 24.

${ }^{37}$ Drugi synod archidiecezji gnieźnieńskiej (16 V 1981), Gniezno 1981, s. 39; Chrystus świattem, s. 93-94; Pierwszy synod diecezji koszalińsko-kotobrzeskiej, s. 78; Drugi polski synod plenarny, s. 92; Uchwaty czterdziestego drugiego synodu płockiego, s. 63; Synod archidiecezji wroctawskiej, s. 285, 304; Trzeci synod diecezji kieleckiej, s. 214.

${ }^{38}$ Drugi polski synod plenarny, s. 80; Synod archidiecezji wroctawskiej, s. 304; Poznański synod archidiecezjalny, s. 289.

${ }^{39}$ Kongregacja Kultu Bożego, Caeremoniale episcoporum (14 IX 1984), nr 230, Città del Vaticano 1984, s. 70. 
1961-1989 dniem tego typu była również uroczystość Wniebowzięcia Najświętszej Maryi Panny (15 sierpnia), a w latach 1961-2010 uroczystość Objawienia Pańskiego (6 stycznia) ${ }^{40}$. W Kościołach partykularnych podejmowano zwłaszcza zagadnienie udziału wiernych w te dni we Mszy św. Powoływano się na dyspensę prymasowską, lecz równocześnie zachęcano do uczestniczenia w Eucharystii bądź w samo święto, bądź wieczorem w jego wigilię. Wyjaśniano przy tej okazji prawo do trynacji oraz sugerowano dodatkowe celebracje eucharystyczne popołudniowe i wieczorne. W osobliwy sposób i na miarę wagi problemu kształtowano świadomość w Kościele Tarnowskim w roku 1986 i Lubaczowskim w roku 1990, zapisując następującą refleksję: „Uroczystości te należy przeżywać w takiej atmosferze], że każdy będzie się czuł zachęcony w tych dniach do udziału w świętej Eucharystii" ${ }^{41}$. Tym samym podzielano w tym względzie przekonanie Kościoła powszechnego o konieczności kierowania się nie tylko możliwością odzyskania dnia wolnego od pracy, ale także tradycją ${ }^{42}$.

\subsection{PRZYGOTOWANIE NIEDZIELNEJ I ŚWIĄTECZNEJ EUCHARYSTII}

Rozwój sposobów i zaangażowania grona osób w dziele przygotowania Eucharystii po II Soborze Watykańskim w niedzielę i obowiązującą znacznie poszerzyły samo pojęcie tego przygotowania ${ }^{43}$. Zasadniczo to

40 Prymas Polski, Udzielenie aż do odwołania dyspensy od obowiazku uczestniczenia we Mszy św. i od powstrzymania się od prac stużebnych w święta "cywilnie zniesione" (8 III 1965), w: Prawodawstwo Kościoła w Polsce, t. 1, tłum. i red. T. Pieronek, Warszawa 1971, s. 102; Kuria Metropolitarna Warszawska, W sprawie praktyki duszpasterskiej odnośnie [do] świąt zniesionych. (Wskazania duszpasterskie), „Wiadomości Archidiecezjalne Warszawskie” 56 (1966), s. 104.

${ }^{41}$ Synod diecezji włoctawskiej, s. 99; Statuty archidiecezjalnego synodu poznańskiego, s. 150, 205; Statuty drugiego synodu gdańskiego, s. 63; Trzeci synod archidiecezji warszawskiej, s. 62; Drugi synod archidiecezji gnieźnieńskiej, s. 63; Czwarty synod diecezji tarnowskiej, s. 76, 122-123; Chrystus świattem, s. 60, 93; Pierwszy synod diecezji koszalińsko-kotobrzeskiej, s. 104; Uchwaty synodu archidiecezji w Lubaczowie, s. 31, 62; Uchwaty czterdziestego drugiego synodu płockiego, s. 63, 77, 435; Drugi synod diecezji włoctawskiej, s. 45.

${ }^{42}$ Jan Paweł II, List apostolski „Dies Domini”, nr 79, s. 27.

${ }^{43}$ M. Pisarzak, Udziat wiernych w przygotowaniu i sprawowaniu niedzielnej Eucharystii, „Ruch Biblijny i Liturgiczny” 47 (1994), s. 206-207; J. Stępczak, Aktywna rola laikatu w (nie tylko) liturgicznym życiu Kościoła na przykładzie parafii francuskiej, "Collectanea Theologica" 67 (1997), z. 3, s. 125-126; R. Pierskała, Niedziela w przekazie dydaktycznym, w: Niedziela w społeczeństwie, s. 112-113; J. Bagrowicz, Świętowanie Dnia Pańskiego - aspekty pedagogiczno-katechetyczne, w: Pamiętaj, abyś dzień, s. 106-107. 
przygotowanie postrzega się w Kościołach partykularnych zarówno jako zadanie duszpasterzy, jak i liturgicznych zespołów w parafii z udziałem liturgicznej służby ołtarza, lektorów, psałterzysty, kantora, komentatora, ministrantów, scholi, organisty, chóru kościelnego, grup modlitewnych oraz innych kręgów formacyjnych. Przygotowanie to polega na uzgodnieniu czytań, śpiewów i pieśni, intencji Modlitwy powszechnej i komentarzy. Wymaga to dostosowania tych ostatnich do homilii ${ }^{44}$. W roku 1986 Kościół Częstochowski zaproponował, żeby przygotowanie do niedzielnej liturgii odbywało się podczas wspólnego spotkania katechetycznego kilku klas szkolnych i zajmowało miejsce drugiej godziny katechezy w ciągu tygodnia $^{45}$.

\subsection{PRZEBIEG I FORMA CELEBRACJI NIEDZIELNEJ I ŚWIĄTECZNEJ MSZY ŚW.}

Po II Soborze Watykańskim nastąpiło znaczne uproszczenie przebiegu i struktury liturgii Mszy św. oraz form jej celebracji. Zniesiono przede wszystkim szereg powtórzeń i dubletów, a uwydatniono poszczególne gesty, znaki itp. Nie oznacza to jednak, że niedziela i obowiązująca uroczystość nie zasługują na wyróżnienie przez odpowiedni sposób celebracji w Kościele partykularnym ${ }^{46}$. Odnośnie do tego sposobu celebracji niedzielnych spotkań eucharystycznych przed Kościołami partykularnymi pojawia się tym samym zadanie rozwijania przymierza z Bogiem oraz zapoczątkowywania apostolatu w codziennym życiu ${ }^{47}$. Szczególnie pod-

${ }^{44}$ Trzeci synod archidiecezji warszawskiej, s. 51, 103, 132; Drugi synod archidiecezji gnieźnieńskiej, s. 38, 123; Chrystus świattem, s. 76, 80; Czwarty synod diecezji tarnowskiej, s. 120, 138; Drugi polski synod plenarny, s. 208; Uchwaty synodu archidiecezji w Lubaczowie, s. 59, 90; Uchwaty czterdziestego drugiego synodu ptockiego, s. 16; Synod archidiecezji wroctawskiej, s. 281, 286, 304, 337; Trzeci synod diecezji kieleckiej, s. 201; Poznański synod archidiecezjalny, s. 70, 93, 185, 256-257.

${ }^{45}$ Chrystus świattem, s. 60-61.

${ }^{46}$ P. Tarliński, Religijny śpiew ludowy w liturgii eucharystycznej dnia Pańskiego, „Liturgia Sacra. Liturgia - Musica - Ars” 3 (1997), nr 2, s. 66-68; I. Pawlak, Muzyka liturgiczna po soborze watykańskim II w świetle dokumentów Kościoła, Lublin 2000, s. 409-410; R. Falsini, dz. cyt., s. 44-45; Ph. Harnoncourt, Die versammelte Gemeinde, s. 46; K. Konecki, dz. cyt., s. 61-62.

${ }^{47}$ Statuty archidiecezjalnego synodu poznańskiego, s. 146; Trzeci synod archidiecezji warszawskiej, s. 51, 100, 114; Drugi synod archidiecezji gnieźnieńskiej, s. 36; Chrystus świattem, s. 93; Drugi synod diecezji lubelskiej, s. 93; Uchwaty czterdziestego drugiego synodu płockiego, s. 63; Synod archidiecezji wroctawskiej, s. 284, 304. 
czas celebracji wszystkich Mszy św. niedzielnych i świątecznych, a nie tylko najliczniej uczęszczanych, uwydatnia się śpiew ${ }^{48}$. Na tej podstawie, za normą w Kościele powszechnym, przyznaje się pierwsze miejsce Mszy św. ze śpiewem i podkreśla się znaczenie udziału ludu w tymże śpiewie, ale pozostawia się również możliwość Mszy św. bez śpiewu ${ }^{49}$. Mszę św. w języku łacińskim w Kościołach partykularnych poleca się w ośrodkach turystycznych oraz podczas zgromadzeń wielojęzycznych ${ }^{50}$. Niedzielnej i świątecznej Eucharystii dotyczy śpiew łatwiejszych aklamacji, dialogów, części stałych i innych melodii gregoriańskich, jak np. Mszy VIII De Angelis (Kyrie, Gloria, Sanctus i Agnus Dei), Credo III i Pater noster (por. KL 54) ${ }^{51}$. Tym samym także w zakresie przebiegu i formy Mszy św. w Kościołach partykularnych mogły urzeczywistniać się określone wzorce Kościoła powszechnego na rzecz przeżywania Mszy św. w duchu wspólnoty i jedności zgromadzenia liturgicznego, zwłaszcza w kościołach parafialnych oraz przy podejmowaniu przez wiernych określonych posług liturgicznych ${ }^{52}$.

\section{NIEDZIELA DNIEM WSPÓLNOTY I RODZINY}

Przeżywanie w niedzielę dnia wspólnoty i rodziny wydaje się głównym celem przeżywania tego dnia w Kościołach partykularnych,

48 Statuty archidiecezjalnego synodu poznańskiego, s. 146, 190; Czwarty synod diecezji tarnowskiej, s. 120, 139; Uchwaty synodu archidiecezji w Lubaczowie, s. 59, 92; Trzeci synod diecezji kieleckiej, s. 221.

${ }^{49}$ Kongregacja Kultu Bożego, Ogólne wprowadzenie, nr 115, s. 48; Kongregacja Kultu Bożego, Instrukcja „Eucharisticum mysterium”, nr 26, s. 171 (nr 26); Kongregacja Kultu Bożego, Instrukcja o muzyce w świętej liturgii „Musicam sacram”(5 III 1967), nr 16, 27, w: Prawodawstwo muzyki liturgicznej, red. A. Filaber, Warszawa 1997, s. 31, 39.

${ }^{50}$ Trzeci synod archidiecezji warszawskiej, s. 100; Wiara, modlitwa $i$ życie, s. 80; Statuty drugiego synodu gdańskiego, s. 114; Duszpasterski synod archidiecezji krakowskiej, t. 1, s. 263; Czwarty synod diecezji tarnowskiej, s. 139; Pierwszy synod diecezji koszalińsko-kotobrzeskiej, s. 38; Uchwaty synodu archidiecezji w Lubaczowie, s. 92; Uchwaty czterdziestego drugiego synodu ptockiego, s. 63.

${ }^{51}$ Wiara, modlitwa i życie, s. 80; Pierwszy synod prowincji krakowskiej, s. 40; Czwarty synod diecezji tarnowskiej, s. 141; Drugi polski synod plenarny, s. 94; Uchwaty synodu archidiecezji w Lubaczowie, s. 95; Uchwaty czterdziestego drugiego synodu ptockiego, s. 63, 74; Synod archidiecezji wrocławskiej, s. 310; Trzeci synod diecezji kieleckiej, s. 223.

${ }^{52}$ Kongregacja Kultu Bożego, Ogólne wprowadzenie, nr 116, s. 48 (nr 116); Kongregacja Kultu Bożego, Instrukcja "Eucharisticum mysterium”, nr 26, s. 171; Kongregacja Kultu Bożego, Instrukcja dotyczaca odprawiania Mszy świętej dla grup specjalnych (15 V 1969), nr 10a, w: To czyńcie, s. 217; Jan Paweł II, List apostolski „Dies Domini”, nr 35, s. 14. 
a zarazem owocem odpowiednich działań i sprawdzianem afirmacji teologii niedzieli po II Soborze Watykańskim ${ }^{53}$. W konsekwencji sporo uwagi poświęca się w Kościołach partykularnych przedłużaniu niedzielnej wspólnoty eucharystycznej w życiu rodzinnym i sąsiedzkim przez liturgię domowa, niedzielne posiłki z bliskimi oraz zwyczaje rodzinne ${ }^{54}$. Wszystko to może przyczyniać się do kształtowania ducha posłannictwa, świadectwa i misji w uczestnikach Eucharystii, a w przyszłości do umocnienia w tym względzie autorytetem nauczania Kościoła powszechnego ${ }^{55}$. W poszczególnych Kościołach partykularnych, jako dzień słowa Bożego, modlitwy i wspólnoty, niedzielę poleca się również łączyć z czytaniem Pisma św. w rodzinach oraz wspólną i indywidualną modlitwą, szczególnie dziękczynną. Czas niedzielny ukazuje się w służbie własnej formacji przez czytelnictwo prasy i książek religijnych. W dni świąteczne wskazuje się na rozmowy rodziców z dziećmi na tematy wiary, odwiedzanie znajomych, samotnych i chorych oraz uczynki miłosierdzia (por. KL 9). Przeżywanie niedzieli i świąt wraz z chorymi obejmuje umożliwienie im uczestnictwa we Mszy św. radiowej czy przekazywanie nagrań i literatury religijnej. Ponadto w roku 1975 w Kościele Katowickim podnoszono problem niedzieli i świąt jako dni bez alkoholu ${ }^{56}$. W Kościele powszechnym znalazło to potwierdzenie $\mathrm{w}$ trosce o kształtowanie postaw solidarności, miłosierdzia, dobroczynności, apostolstwa i w ogóle zaangażowania ${ }^{57}$. Zarazem

${ }^{53}$ H. Simon, Niedziela jako dzień stowa Bożego. Zbawczy i wspólnototwórczy charakter liturgii stowa, w: Wielkanoc i niedziela. W 30. rocznice ogtoszenia Konstytucji o liturgii "Sacrosanctum Concilium" soboru watykańskiego II, Opole 1994, s. 137-138; S. Cichy, Niedziela w rodzinie, „Ruch Biblijny i Liturgiczny” 34 (1981), s. 46-49; Rytuat rodzinny. (Aby rodzina była bardziej Kościołem), red. J. Wysocki, Olsztyn 1985, s. 226; J. Bagrowicz, dz. cyt., s. $85-86$.

${ }^{54}$ Statuty archidiecezjalnego synodu poznańskiego, s. 244; Trzeci synod archidiecezji warszawskiej, s. 133; Wiara, modlitwa $i$ życie, s. 60-61; Duszpasterski synod archidiecezji krakowskiej, t. 1, s. 335-336; Drugi synod archidiecezji gnieźnieńskiej, s. 97; Chrystus świattem, s. 120-121, 202; Drugi synod diecezji lubelskiej, s. 93-94, 139, 158; Czwarty synod diecezji tarnowskiej, s. 133, 222, 235; Drugi polski synod plenarny, s. 77, 325; Uchwaty synodu archidiecezji w Lubaczowie, s. 80, 181, 203; Synod archidiecezji wroctawskiej, s. 220, 304, 446; Trzeci synod diecezji kieleckiej, s. 123; Poznański synod archidiecezjalny, s. 167, 266.

55 Jan Paweł II, List apostolski „Dies Domini”, nr 45, s. 18.

${ }^{56}$ Trzeci synod archidiecezji warszawskiej, s. 133; Wiara, modlitwa i życie, s. 58; Czwarty synod diecezji tarnowskiej, s. 133, 215; Chrystus świattem, s. 120-121; Drugi synod diecezji lubelskiej, s. 94, 139, 158; Drugi polski synod plenarny, s. 77; Uchwaty synodu archidiecezji w Lubaczowie, s. 80, 169; Synod archidiecezji wroctawskiej, s. 131, 141, 213, 284, 303-304; Trzeci synod diecezji kieleckiej, s. 211, 219; Drugi synod diecezji włocławskiej, s. 22.

${ }^{57}$ Jan Paweł II, List apostolski „Dies Domini”, nr 69, s. 24. 
w Kościele Lubaczowskim w 1990 roku nawiązywano do tradycji wydawania przed II wojną światową Gazety Niedzielnej z dodatkiem Słowo Boże jako tygodnika dla rodzin katolickich ${ }^{58}$. W szczególności warto zaznaczyć, że w Kościele Wrocławskim i Poznańskim w roku 1993 uwrażliwiano na przygotowanie $\mathrm{w}$ rodzinie do niedzielnych czytań biblijnych. Według tych zamierzeń, przygotowanie to odbywa się w sobotę i polega na zaznajomieniu z czytaniami, na lekturze komentarzy i wprowadzeń z bieżącej prasy czy kalendarzy katolickich. Po powrocie z kościoła poleca się rodzinną rozmowę na temat usłyszanego słowa Bożego (por. KL 52; KO 21) ${ }^{59}$. Mogło to jednocześnie, z perspektywy Kościoła powszechnego, dowartościowywać karmienie się słowem Bożym podczas Mszy św. ${ }^{60}$ Inne formy przeżywania niedzieli w duchu wspólnoty, zaproponowane przez Kościół Warszawski w roku 1974, to także tradycyjne nabożeństwa dodatkowe wraz z żywym udziałem w nich wiernych ${ }^{61}$.

\section{NIEDZIELA DNIEM ODPOCZYNKU}

Odpoczynek na wzór Bożego odpoczynku na zakończenie dzieła stworzenia zdaje się zajmować nadal pierwsze miejsce wśród innych motywacji do przeżywania niedzieli ${ }^{62}$. Zwłaszcza w Kościele Kieleckim w roku 1992 i Wrocławskim w roku 1993 nawiązywano w tym względzie do teologicznych podstaw odpoczynku w Starym i Nowym Testamencie aż po eschatyczną zapowiedź życia wiecznego. W ogóle jednak w Kościołach partykularnych często apelowano do władz państwowych, aby nie organizowały w niedziele ani pracy etatowej, ani społecznej. Sygnalizowano złą organizację wypoczynku oraz niedostateczne wychowanie rodzinne $\mathrm{w}$ dziedzinie świętowania ${ }^{63}$. Tym samym stałą troską w życiu

${ }^{58}$ Uchwaty synodu archidiecezji w Lubaczowie, s. 15.

59 Synod archidiecezji wroctawskiej, s. 140; Poznański synod archidiecezjalny, s. 73$-74,290$.

${ }^{60}$ Kongregacja Kultu Bożego, Instrukcja "Eucharisticum mysterium”, nr 10, s. $162-163$.

${ }^{61}$ Trzeci synod archidiecezji warszawskiej, s. 51.

62 J. Kowalski, Humanistyczny wymiar niedzieli, w: Niedziela dzisiaj, red. J. Krucina, Wrocław 1993, s. 144-145; A. Bugnini, La reforma liturgica (1948-1975), Roma 1983, s. 320-321; B. Nadolski, Antropologiczno-kulturowe walory niedzieli w dzisiejszym społeczeństwie, w: Niedziela w społeczeństwie, s. 48-49; J. Gręźlikowski, Prawne aspekty świętowania niedzieli, w: Pamiętaj, abyś dzień, s. 141-142.

${ }^{63}$ Trzeci synod archidiecezji warszawskiej, s. 133; Wiara, modlitwa $i$ życie, s. 60-61, 256; Duszpasterski synod archidiecezji krakowskiej, t. 1, s. 340-341; Czwarty synod diecezji 
Kościołów partykularnych pozostaje wypoczynek niedzielny i świąteczny, czynny i pogłębiony jako zapowiedź wiecznego życia i wieczystej liturgii (por. KDK 61). Formację wiernych w tym kierunku zapewnia spędzanie wolnego czasu na rekreacji, turystyce, odnowie życia wewnętrznego, rozwijaniu duchowych zainteresowań oraz rodzinnej rozrywce. Neguje się lenistwo oraz bierne oglądanie telewizji itp. ${ }^{64} \mathrm{~W}$ ten sposób wrażliwość Kościołów partykularnych mogła stawać się podłożem do refleksji Kościoła powszechnego nad znaczeniem prawa do odpoczynku i odprężenia oraz ubogacenia duchowego $\mathrm{w}$ teologii pracy przy realiach niesprawiedliwości i wyzysku oraz zapewnienia wolności, godności człowieczeństwa i prymatu Boga w zapowiedzi „nowego nieba” i „nowej ziemi”"65. Pod rozwagę wiernych ogółu Kościołów partykularnych diecezji polskich w roku 1991 poddawano także myśl, że niedzielny i świąteczny odpoczynek może oznaczać pisanie listów, rozmowy telefoniczne, spotkania z kulturą, teatr, kino, zwiedzanie muzeów, wystaw czy zabytków oraz czas na spotkanie z przyrodą i uświadomienie sobie obowiązków ekologicznych ${ }^{66}$. W odniesieniu do sportu i turystyki kierowano apel o większe zaangażowanie ludzi związanych z Kościołem w organizację czasu wolnego ${ }^{67}$. Innego rodzaju oryginalną propozycję przedstawiano w roku 1970 w Kościele Poznańskim, a potem również w Kościele Tarnowskim w roku 1986, Lubaczowskim w roku 1990 i Kieleckim w roku 1992. Dotyczy ona organizowania na początku sezonu urlopowo-wakacyjnego „niedzieli turystyki” z dostosowaną Liturgią słowa podczas Mszy św., homilią na temat religijnego charakteru wypoczynku oraz Modlitwą wiernych ${ }^{68}$. Nadto celebrację okolicznościowej Mszy św. dla

tarnowskiej, s. 132, 235; Chrystus świattem, s. 120-121; Uchwaty synodu archidiecezji w Lubaczowie, s. 80, 203; Uchwaty czterdziestego drugiego synodu płockiego, s. 77; Synod archidiecezji wroctawskiej, s. 303; Trzeci synod diecezji kieleckiej, s. 274-275.

${ }^{64}$ Statuty archidiecezjalnego synodu poznańskiego, s. 18, 97, 99; Trzeci synod archidiecezji warszawskiej, s. 51, 133, 202; Pierwszy synod prowincji krakowskiej, s. 70; Czwarty synod diecezji tarnowskiej, s. 173, 215, 222, 235; Chrystus świattem, s. 120; Drugi synod diecezji lubelskiej, s. 94, 139, 158; Drugi polski synod plenarny, s. 77, 325; Uchwaty synodu archidiecezji w Lubaczowie, s. 169, 181, 203; Synod archidiecezji wroctawskiej, s. 213, 304; Trzeci synod diecezji kieleckiej, s. 211, 219; Poznański synod archidiecezjalny, s. 167.

${ }^{65}$ Jan Paweł II, List apostolski „Dies Domini”, nr 66, 68, s. 23-24.

${ }^{66}$ Drugi polski synod plenarny, s. 325.

${ }^{67}$ Tamże, s. 324.

${ }^{68}$ Statuty archidiecezjalnego synodu poznańskiego, s. 98; Czwarty synod diecezji tarnowskiej, s. 244; Uchwaty synodu archidiecezji w Lubaczowie, s. 218; Trzeci synod diecezji kieleckiej, s. 278. 
wyjeżdżających i powracających z wakacji przewidziano się w Kościele Gdańskim w roku $1973^{69}$.

Zagadnieniem odpoczynku w dni świąteczne tzw. zniesione przez państwo, a nie tylko udziałem we Mszy św., zajmowano się szczególnie w Kościele Tarnowskim i Częstochowskim w roku 1986, Lubaczowskim w roku 1990 i Płockim w roku 1991. Opierając się na dyspensie prymasowskiej o powstrzymaniu się od pracy w te dni, zobowiązywano duszpasterzy do przypominania wiernym o tych dniach świątecznych (por. KPK 1244 § 1). Zachęcano również do unikania wówczas zakupów i załatwiania spraw urzędowych oraz apelowano do rodziców i wychowawców, aby przeciwdziałali zamierzonej desakralizacji świąt (por. KPK $1246 \S 1-2)$. W warunkach katechizacji przykościelnej wskazywano, że te dni są wolne od nauki religii ${ }^{70}$.

Podsumowując, należy wskazać, że życie Kościoła partykularnego wielorako przenika się nawzajem z rzeczywistością niedzieli w duchu odnowy liturgii po II Soborze Watykańskim.

1. Nie jedynym, ale dogodnym i łatwym w dostępie sposobem na wgląd w życie Kościołów partykularnych okazują się synody tych Kościołów w duchu wspólnoty refleksji nad rozwojem wiary i liturgii. Synody te w latach 1967-1994 odsłaniały rzeczywistość niedzieli w życiu Kościołów partykularnych. Według kolejności organizowania synodów można wymienić piętnaście Kościołów partykularnych: Włocławski, Poznański, Gdański, Warszawski, Katowicki, Krakowski, Gnieźnieński. Tarnowski, Częstochowski, Lubelski, Koszalińsko-Kołobrzeski, Lubaczowski, Płocki, Kielecki, Wrocławski. Przy czym świadectwo życia Kościoła Włocławskiego i Poznańskiego wzmacnia fakt, że zorganizowały one po dwa synody. Nadto świadectwo życia Kościoła Krakowskiego oprócz synodu archidiecezjalnego poszerza synod prowincjalny. Życie ogółu Kościołów partykularnych diecezji polskich oddają także dokumenty synodu plenarnego. Świadectwa życia Kościołów partykularnych w latach 1967-1994 zachowują swoją aktualność i ukazują życie Kościoła partykularnego w ogóle.

69 Statuty drugiego synodu gdańskiego, s. 117.

${ }^{70}$ Czwarty synod diecezji tarnowskiej, s. 76, 122-123; Chrystus świattem, s. 60, 93; Uchwaty synodu archidiecezji w Lubaczowie, s. 31, 62; Uchwaty czterdziestego drugiego synodu ptockiego, s. 63, 77, 435. 
2. Rzeczywistość niedzieli w życiu Kościoła partykularnego wzmacnia pojęcia, zadania i znaki wiary, takie jak udział, zaangażowanie, wspólnota, współdziałanie, otwartość, przygotowanie, urozmaicenie, pogłębienie, radość wiary, rozwój przymierza z Bogiem, apostolstwo, życie wiarą. Ta rzeczywistość i jej stan w życiu Kościoła partykularnego często wymaga samooceny, wyjaśniania, uzasadnienia potrzeby zmian, zachęty itp.

3. Niedziela obejmuje swoim oddziaływaniem zwłaszcza parafie, ale w skali parafii może aktywizować także grupy duszpasterskie i parafialne, ruchy katolickie, zespoły liturgiczne w parafii itp. Dotyka głębi życia i wiary oraz takich realiów życia, jak wczasy, wakacje, wycieczki, zajęcia sportowe, obozy, kolonie.

4. Przed Kościołami partykularnymi w obliczu niedzieli otwiera się bogactwo zwyczajów. Jedne z nich zasługują na wzmacnianie i rozwój. Inne wymagają korekty czy zaniechania.

\section{THE SUNDAY IN THE LOCAL CHURCH}

\section{SUMMARY}

The local Synods which took place after the Council, have given us an insight into the importance of Sunday. The diocesan Synods took place in Włocławek, Poznań, Gdańsk, Warszawa, Katowice, Kraków, Gniezno, Tarnów, Częstochowa, Lublin, Koszalin-Kołobrzeg, Lubaczów, Płock, Kielce, Wrocław in Poland in period of 1967-1994. The Synods' documnets talk about the role of Sunday in the Christian life. According to the documents, the faith grows througth the new experience of celebration of Pascha and reneval of the convenant with God. This leads to joy in God, hope and peace as the Christians engage more in the community and in the apostolate. A local synod does self-reflection and explains the need for change in the Christian life on Sunday. The parishes should activate the pastoral teams, the ecclesial movements and the liturgical services on Sundays. There are some new pastoral problems such as holiday vacation and trips on the Sundays. Some Sunday habits need to be improved, but some should be rejected. 